\title{
ATLAS OF WOOD PELLET COMPONENTS
}

\author{
Agnieszka Drobniak ${ }^{1}$, Zbigniew Jelonek², Maria Mastalerz'1 I Iwona Jelonek² \\ ${ }^{1}$ Indiana Geological and Water Survey, Indiana University, 1001 E. 10th St., Bloomington, IN, 47405, USA \\ 2 University of Silesia in Katowice, Institute of Earth Sciences, ul. Będzińska 60, 41-200 Sosnowiec, Poland \\ E-mail: agdrobni@indiana.edu \\ Received 02/03/2021 \\ Accepted for publication 03/29/2021 \\ (c) \\ Published 04/19/2021 \\ Suggested citation: Drobniak, A., Jelonek, Z., Mastalerz, M., Jelonek, I., 2021, Atlas of Wood Pellet Components: Indiana Geologi- \\ cal and Water Survey, Indiana Journal of Earth Sciences, v. 3. DOI 10.14434/ijes.v3i1.31905.
}

Editor's Note: This manuscript links to an online atlas of wood-pellet photomicrographs stored on Resource Space at the IGWS:

http://go.iu.edu/woodpelletatlas

Concerns about climate change, energy security, and the diversification of energy supplies have made renewable resources increasingly more attractive and important sources of energy. As interest grows, bioenergy (energy from bio-based sources) is becoming more environmentally friendly and economically viable and has started to play a more prominent role in the global energy mix (Bioenergy Europe, 2020; BP, 2020; PFI, 2020). In this changing market, wood pellets have emerged as a sustainable source of power with the potential to become a mainstream fuel in the future energy market.

For the last several years, the wood pellet market has grown continuously, with both production and consumption steadily increasing worldwide. Pellet production in 2019 reached 39.5 million tons worldwide and was valued at US\$10.491 billion. Manufacturing capacity in the United States increased over the past decade to meet growing European demand for renewable energy and continues to be driven by export-oriented projects. It reached 9.5 million tons in 2019, increasing by 15 percent from 2018. According to the Pellet Fuel Institute (PFI, 2020), approximately 1 million homes in the United States currently use wood pellets for heating. The remainder of U.S. pellet production is exported, predominantly to the United Kingdom, which continues to be the largest consumer of pellets (mostly for power generation), using almost 9.2 million tons in 2019 (Bioenergy Europe, 2020). While for the last several years the vast majority of wood pellets were produced for industrial and residential heating and for generating power, in recent years consumers can also purchase wood pellets
(BBQ pellets) that are marketed specifically for grilling. Although production numbers are unknown, using wood pellets for outdoor cooking is one of the hottest trends in the grilling industry, and the use of BBQ pellets is expected to grow.

The increasing production and consumption of wood pellets and the wide variety of materials used in their manufacture have brought up the question of how to assure pellet quality. While wood smoke contains more than 200 distinct organic compounds, many of which have been shown to cause acute or chronic health effects and to pollute the atmosphere (Naeher and others, 2007), limited research has been conducted to understand the relationship between the quality of wood pellets and the impact of their combustion emissions on human safety and the environment. This is especially critical in the case of $\mathrm{BBQ}$ wood pellets, as smoke from their combustion has direct contact with food and the emissions are inhaled during grilling (Jelonek and others, 2020b, 2021).

Our research shows that wood pellets can contain an wide array of contaminants. Some impurities come from the structure of the wood itself, its harvesting method, and transportation. Others, like metal, rust, oils, and grease, can be introduced during the manufacturing process. Such impurities cannot be avoided and are acceptable at low levels. However, additional contaminants can result from machinery malfunctions or inadequate wood source material (old furniture or construction materials that contain glues, resins, or paint). In some instances, their presence is a result of the lack of attention (pieces of plastic 
bags), or they can be intentionally added (plastic and tire rubber) to make ignition easier and increase heat output. These examples show that pellet testing is of critical importance because the presence of these contaminants can lead to emissions of carcinogenic compounds and harmful particulate matter suspended in smoke (Jelonek and others, 2020a, b, 2021) (figs. 1, 2; Tables 1, 2).

Concerns about the quality of wood pellets have led to establishing a European standard in 2011 (EN-14961-2:2012), followed by the development of an international standard (ISO 17225-2:2014) a few years later. Following these standards, the ENplus ${ }^{\circledR}$ certification was created by the German Pellet Institute, and an accreditation program of the Pellet Fuel Institute (PFI) was established in the United States. Some wood pellet manufacturers now follow rigorous production procedures and certification, especially in North America and the European Union. However, many manufacturers still do not follow the same production standards. Our research shows that, in some extreme cases, these uncertified wood pellets contain more than 20 percent impurities. While some of those contaminants are so large that they are visible with the naked eye, most of the impurities are at a micrometer scale and can be detected and identified only under a microscope (figs. 1,2).

The current standards test the quality of pellets based on a variety of physical and chemical properties, but some impurities (glass, plastic, rubber, metal, ceramics, coal, and coke) are not easily identified this way. Our research shows that optical microscopy can be successfully used to identify and quantify those contaminants. Although reflected light microscopy is a well-known and widely used method that allows various materials to be examined, including geological specimens and rocks, it is a novel application for wood pellets. This methodology, developed by our research team (Jelonek and others, 2020a, b), has proved to be an excellent tool for quality testing, and it can help enhance production of superior pellet fuels. This analytical method is already recognized and implemented as obligatory for testing for inadmissible additions in grilling charcoal briquettes (EN 1860-2:2005).
In our pellet fuels research (Jelonek and others, 2020a, b, 2021), we have analyzed a large number of wood pellets and collected thousands of photomicrographs of various pellet components. This "Atlas of Wood Pellet Components" features more than 300 photographs taken between 2019 and 2021 while we developed the method of using reflected light microscopy to identify pellet fuel constituents. These photomicrographs provide documentation of the composition of wood pellets and demonstrate the array of impurities that can be present. As such, this atlas is a valuable source of information for anyone interested in pellet fuels, optical microscopy, and quality assessment techniques.

\section{References Cited}

BioEnergy Europe, 2020, Statistical Report-pellets: URL at https://bioenergyeurope.org/about-bioenergy.html, accessed March 30, 2021.

BP, 2020. Statistical review of world energy, 69th ed., 2020: BP, URL at https://www.bp.com/en/global/corporate/ energy-economics/statistical-review-of-world-energy.html, accessed March 30, 2021.

European Standard (EN), 2012, EN-14961-2:2012, Solid biofuels-Fuel specification and classes-Part 2-Wood pellets for non-industrial use.

European Standard (EN), 2005, EN 1860-2:2005-Appliances, solid fuels and firelighters for barbecueing-Part 2-Barbecue charcoal and barbecue charcoal briquettes-Requirements and test methods: URL at https://www.techstreet.com/ searches/27126501, accessed March 30, 2021. ISO Standard, 2014, 17225-2:2014-Solid biofuelsFuel specifications and classes-Part 2-Graded wood pellets: URL at https://www.iso.org/standard/59457. html, accessed March 30, 2021.

Jelonek, Z., Drobniak, A., Mastalerz, M., and Jelonek, I., 2021, Environmental and human health implications of grilling with wood pellets and chips: Atmospheric Environment $X$, in review.

Jelonek, Z., Drobniak, A., Mastalerz, M., and Jelonek, I., 2020a, Assessing pellet fuels quality-a novel application for reflected light microscopy: International Journal of Coal Geology, v. 222, 103433. https://doi. org/10.1016/j.coal.2020.103433.
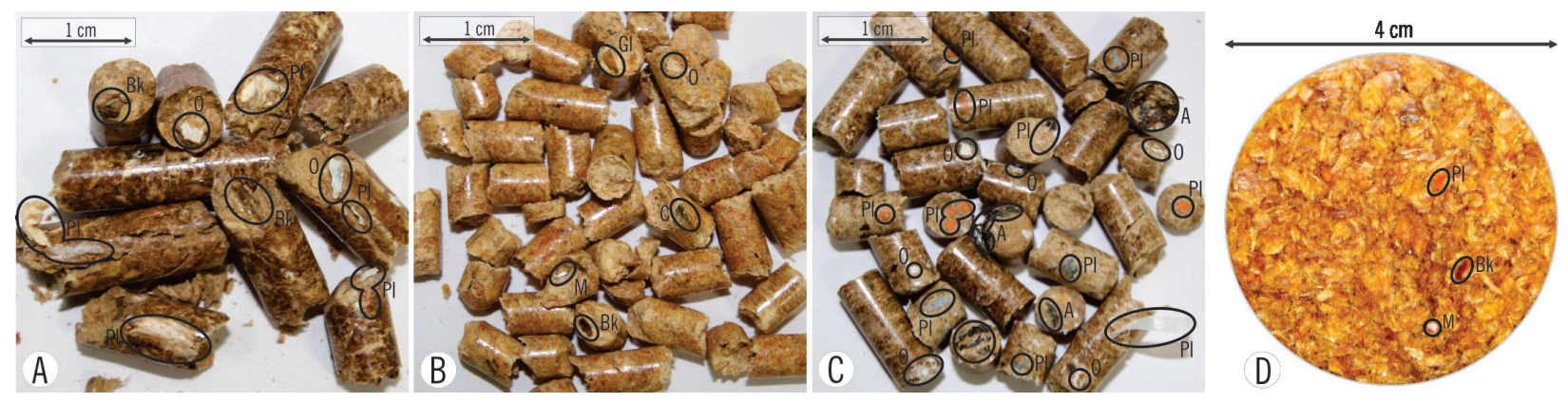

Figure 1. Wood pellets having very high contents of impurities that are visible megascopically in raw samples $(A-C)$ and a microscope plug (D). $A=$ ash, $B k=$ bark, $C=$ coal, $\mathrm{Gl}=$ glass, $M=$ metal, $O=$ binder, $\mathrm{Pl}=$ plastic. $1 \mathrm{~cm}=0.39$ inch. 

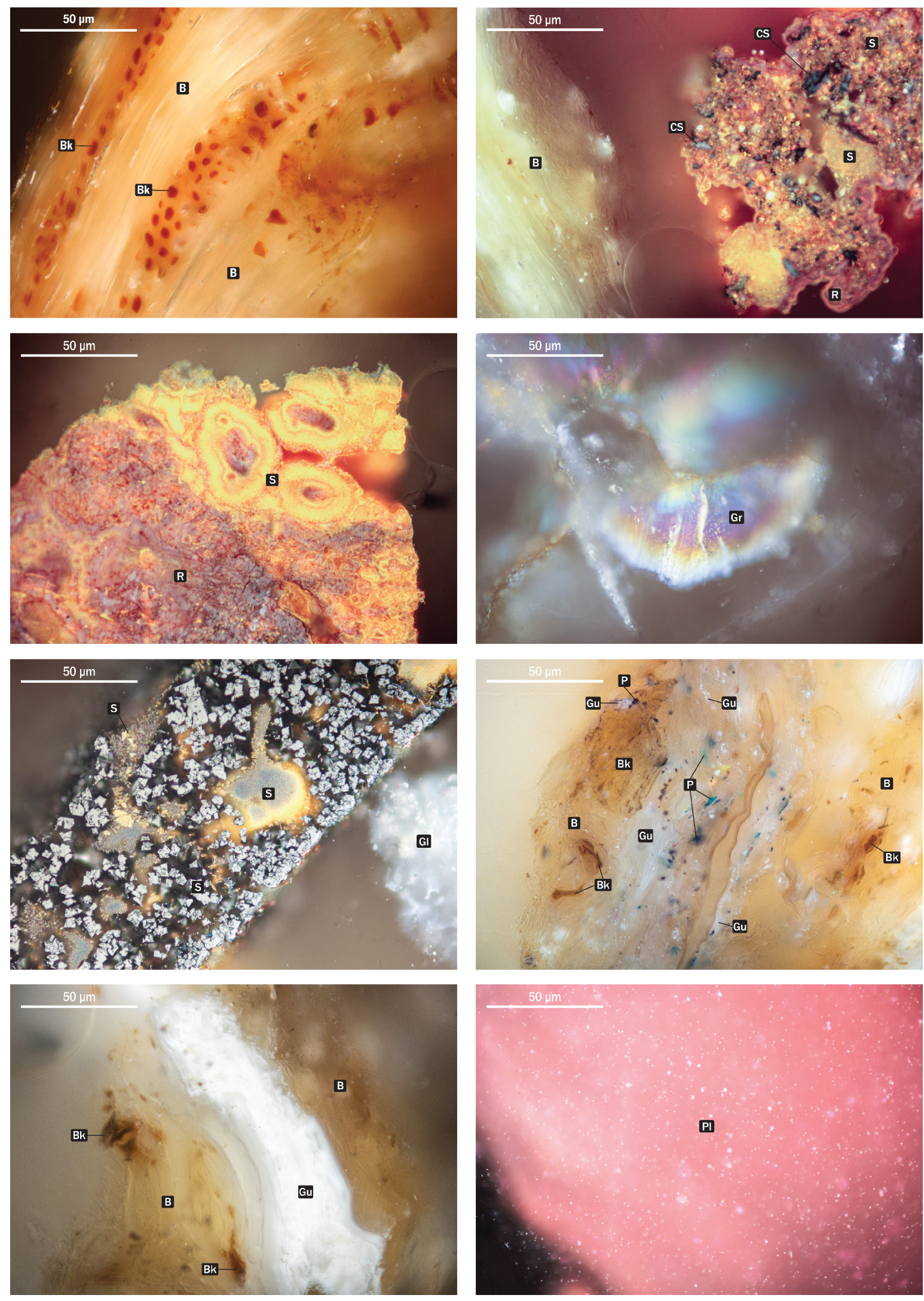

Figure 2. Photomicrographs of selected wood pellet components in reflected white light and oil immersion. $\mathrm{B}=$ biomass, $\mathrm{Bk}=$ bark, $\mathrm{CS}=$ coal in slag, $\mathrm{Gl}=$ glass, $\mathrm{Gr}=$ grease, $\mathrm{Gu}=$ glue, $\mathrm{P}=$ paint, $\mathrm{Pl}=$ plastic $\mathrm{S}=$ slag, $\mathrm{R}=$ rust. 
Table 1. Petrographic classification of wood pellets components (modified from Jelonek and others, 2020a).

\begin{tabular}{|c|c|c|}
\hline \multicolumn{3}{|l|}{ Biomass (B) } \\
\hline \multicolumn{3}{|l|}{ Bark (Bk) } \\
\hline \multicolumn{3}{|l|}{ Coal (C) } \\
\hline \multicolumn{3}{|l|}{ Coal in slag (CS) } \\
\hline \multicolumn{3}{|l|}{ Charcoal (Ch) } \\
\hline \multicolumn{3}{|c|}{ Charcoal in slag (ChS) } \\
\hline \multicolumn{3}{|c|}{ Coke (Co) } \\
\hline \multicolumn{3}{|l|}{ Coke in slag (CoS) } \\
\hline \multicolumn{3}{|l|}{ Metal (M) } \\
\hline \multicolumn{3}{|l|}{ Metal in slag (MS) } \\
\hline \multicolumn{3}{|l|}{ Rust (R) } \\
\hline \multicolumn{3}{|l|}{ Rust in slag (RS) } \\
\hline \multirow{2}{*}{$\begin{array}{l}\text { Mineral matter } \\
(\mathrm{MM})\end{array}$} & Thermally unchanged & $\begin{array}{l}\text { Sand (Sd) } \\
\text { Quartz (Qz) } \\
\text { Stone powder (SP) }\end{array}$ \\
\hline & $\begin{array}{l}\text { Thermally / } \\
\text { Technologically changed }\end{array}$ & $\begin{array}{l}\text { Ceramic (Cr) } \\
\text { Glass (Gl) } \\
\text { Sand/clay product (SC) }\end{array}$ \\
\hline \multicolumn{3}{|c|}{ Mineral matter in slag (MMS) } \\
\hline \multicolumn{3}{|l|}{ Slag (S) } \\
\hline $\begin{array}{l}\text { Petroleum } \\
\text { product } \\
\text { (PP) }\end{array}$ & $\begin{array}{l}\text { Plastic (PI) } \\
\text { Rubber (Rb) } \\
\text { Liquid petroleum fuels (LP) } \\
\text { Grease (Gr) } \\
\text { Glue }(\mathrm{Gu}) \\
\text { Polymer resin (PR) }\end{array}$ & \\
\hline \multicolumn{3}{|l|}{ Paint $(P)^{*}$} \\
\hline \multicolumn{3}{|l|}{$\operatorname{Ash}(A)$} \\
\hline Other (binders anc & servatives) (0) & \\
\hline
\end{tabular}

* Some paints are petroleum based.

Jelonek, Z., Drobniak, A., Mastalerz, M., and Jelonek, I., 2020b, Environmental implications of the quality of charcoal briquettes and lump charcoal used for grilling: Science of Total Environment, v. 747. https://doi.org/10.1016/j.scitotenv.2020.141267.

Naeher, L. P, Brauer, M., Lipsett, M., Zelikoff, J. T., Simpson, C. D., Koenig, J. Q., and Smith, K. R., 2007,
Wood smoke health effects-a review: Inhalation Toxicology, v. 19, no. 1, p. 67-106. https://doi. org/10.1080/08958370600985875.

Pellet Fuels Institute (PFI), 2020, Pellet Fuels Institute website: URL at https://www.pelletheat.org/, accessed March 30, 2021. 
Table 2. Major components of pellet fuels, their sources, and their influence (see full reference list in Jelonek and others, 2021, in review).

\begin{tabular}{|c|c|}
\hline Biomass & $\begin{array}{l}\text { Main component of wood pellets. Linked to potentially harmful particulate matter and smog emissions. It } \\
\text { can contain glued, painted, and chemically processed wood; soil, and sand inclusions from harvesting and } \\
\text { transportation; or manufacturing dust. }\end{array}$ \\
\hline Bark & $\begin{array}{l}\text { Often associated with biomass. Might contain elevated mineral matter content (like soil or sand from trans- } \\
\text { portation) and produce more ash than wood. Linked to potentially harmful particulate matter and smog } \\
\text { emissions. }\end{array}$ \\
\hline Charcoal & $\begin{array}{l}\text { Occasionally found in wood pellets. Produces a significant amount of ash and odor, but, more importantly, } \\
\text { charcoal smoke can contain substances having carcinogenic and mutagenic activity, like particulate matter, } \\
\text { black carbon, heterocyclic amines, polycyclic aromatic hydrocarbons, or carbon monoxide, which can lead to } \\
\text { an increased risk of chronic bronchitis, emphysema, and respiratory tract cancer. }\end{array}$ \\
\hline Coal & $\begin{array}{l}\text { Usually introduced secondarily (storage facilities) but can be added intentionally to reduce moisture content } \\
\text { and increase calorific value. Increases the formation of ash, slag, and } \mathrm{CO}, \mathrm{CO}_{2} \text {, and } \mathrm{SO}_{\mathrm{x}} \text { emissions. Contributes }\end{array}$ \\
\hline Coke & combined with alkaline ash, lead to faster corrosion of the combustion chamber, chimney, or grill. \\
\hline $\begin{array}{l}\text { Mineral } \\
\text { matter }\end{array}$ & $\begin{array}{l}\text { Various types of mineral matter have also been identified in pellets; examples include quartz grains, } \\
\text { glass, and ceramics. Originates as impurities filling void spaces in the bark or wood cells and may be } \\
\text { introduced as loose grains of sand or soil during logging or transport. It increases the weight of the prod- } \\
\text { uct, and as a result, consumers pay a higher price for a contaminated product. There is a direct relationship } \\
\text { between the amount of mineral matter present in pellets and the amount of slag and soot formed; over } \\
\text { time, this will negatively affect grill or boiler operation and life span. Makes it more difficult to ignite the } \\
\text { pellet fuels, which may prompt the use of flammable substances (harmful to humans and the environment) } \\
\text { to make ignition easier. }\end{array}$ \\
\hline $\begin{array}{l}\text { Metal and } \\
\text { rust }\end{array}$ & $\begin{array}{l}\text { Introduced as particles and scraps during the production process. Their presence increases the weight of the } \\
\text { product and the amount of ash created upon combustion, and along with other contaminants (for example, } \\
\text { bark and mineral matter) form slag agglomerates. }\end{array}$ \\
\hline $\begin{array}{l}\text { Petroleum } \\
\text { products }\end{array}$ & $\begin{array}{l}\text { Most often comes either from the source material (like glue, paint, or synthetic resin from old furniture) or } \\
\text { introduced during the manufacturing process (plastics, rubber, and grease). These affect the quality of } \\
\text { combustion gases and lead to the emission of carcinogenic compounds and harmful particulate matter } \\
\text { suspended in smog. }\end{array}$ \\
\hline
\end{tabular}

